\title{
Environmental Sustainability Program Implementation of Public Schools of General Santos City: Basis for Environmental Advocacy Framework
}

\author{
Ava Clare Marie O. Robles, Ph.D. \\ College of Education, Mindanao State University \\ General Santos City, Philippines \\ Tel: (63906)-269-4258Ｅ-mail: ching08robles@gmail.com \\ Estela Marie O. Verana, DM (Corresponding author) \\ Graduate School, Mindanao State University \\ General Santos City, Philippines \\ Tel: (63919)-666-5479Ｅ-mail: everana26@gmail.com
}

Received: July 9, 2012 Accepted: July 24, 2012

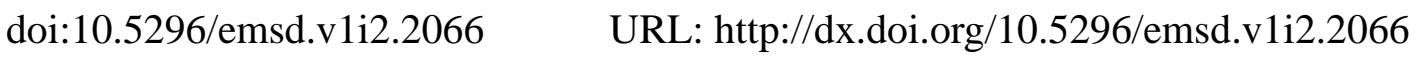

\begin{abstract}
The massive destruction brought by "Bagyong Sendong" in 2011 shook the people in Mindanao, with the realization that the only hope to recover from this grave condition is by making every person conscious to protect the environment. With this tragedy, it is of great importance that Department of Education (DepEd) officials, students, and teachers must: synergize toward environmental sustainability, serve as agents to boost public environmental awareness and demonstrate commitment to environmental protection.

Realizing the truth of these words, this study determined the level of implementation of the environmental sustainability program of the selected public schools in General Santos City (GSC). In addition, this study proposes an innovative environmental framework to promote environmental education, which is an indispensable means to attain environmental awareness that addresses environmental issues. The respondents of this study were the 350 public elementary and high school teachers. Results of the study revealed that the environmental program of selected public schools in GSC was implemented only to a moderate extent.
\end{abstract}


Finally, recommendations on how to effectively promote innovative environmental advocacy, which may lead to significant enhancements to environmental awareness, were also discussed in this study.

Keywords: Environmental Sustainability, Environmental Advocacy

\section{Introduction}

21st century is a period of converging social, economic and environmental crises. Today, the climatic condition has become distorted in many ways that the health of several crucial ecology services is also at stake. In view of numerous erroneous environmental practices damaging the environment in exchange for technology, issues concerning environmental sustainability are now one of the research goals here and abroad.

Currently, people's interaction with the environment has amplified rapidly in response to population escalation, speedy technological advancement, and agricultural upgrades. These, however, may cause desolation due to deficient water, energy and other basic resources, as well as transport of significant change that will generate instabilities in the environment.

The conspicuous tragedy brought by "Bagyong Sendong” in 2011 has paved way for the community's realization and involvement in the protection of the environment. Schools play a vital role in environmental development, sustainability and dissemination of ideas. This requires everyone at schools - teachers, researchers, students, administrators and community--- to draw-up action plans to ensure that education supports the development of environmental awareness and sustainability. At present, our society needs government leaders with transformed perspective towards environmental sustainability since leaders have special responsibilities in promoting environmental education as one of the key agents to achieve sustainable development. Likewise, educational systems must also be encouraged to support environmental sustainability programs like campus greening.

This, however, needs an environmental protection program which necessitates synergy among various institutions and government offices to demonstrate their role towards sustainability of the environment. One way to reach this stage is by having an innovative advocacy framework for schools that promote the implementation of the environmental sustainability programs in schools of General Santos City.

Thus, this study determined the level of implementation of the Environmental Sustainability Program among the selected public schools in General Santos City. It is hoped that this research will enable the DepEd officials, students, teachers and parents in the community to be responsive to the current need of the society where they serve. It is believed that the school's environmental sustainability program implementation can be improved further if a realistic advocacy framework is developed.

\subsection{Statement of the Problem}

This study investigated the level of environmental sustainability program implementation of selected public schools of General Santos City (GSC). To realize the intention of the study, the researchers attempted to answer the following specific problems: 
1. What is the level of environmental sustainability program implementation of selected Elementary and Secondary schools?

2. Is there a significant difference on the level of environmental sustainability program implementation between the selected elementary schools and secondary schools of General Santos City as perceived by teachers?

3. Based on the result of the study, how may an environmental advocacy framework be proposed?

\section{Review of Literature}

Researchers worldwide understand sustainability as one of the most significant ideas of this century; that its application and consciousness will determine the continued existence of humanity. Consequently, it is necessary for each individual to have a deeper comprehension for this concept. According to Jucker (2003) sustainability is achieved when all people can live well without compromising the quality of life for future generations.

Undeniably, managing the environment is an enormous task that schools have to work with not only for the reason that it is a mandate by the Local Government Code, but more importantly because failure to address environmental issues would destabilize the development efforts and impinge people's life and welfare.

For Greene (2008) schools can serve as center for change, innovation and progress, as well as role model. He further argued that as leader for the community, schools must build student the capacity to do critical thinking and problem solving in terms of environmental issues. In fact, DENR Secretary Ramon Paje (2011) highlighted that schools should start teaching students at an early stage to take responsibility in safeguarding the environment for he believed that' schools are dynamic focal points of learning and powerful vehicles of change.

In the Philippine setting, initiatives implemented like the farming system was undertaken to institute environmental sustainability program. Concrete evidence was based from Briones (2005) who claimed that the initiatives from different divisions to diminish the unfavorable ecological impact of farming systems and to guard the farming assembly bases are in position and in requisites to policies, programs, and action projects.

Moreover, the establishment of school-based solid waste management initiative sought to enhance the capacity of students' waste management at the same time train and empower the students, teachers, and school administrators to create their own school-based solid waste management program (Baula, 2010).

Implementation has been operationally defined, in this study as the degree of realization or execution of environmental sustainability programs in selected public schools in General Santos City.

While each institution is expected to craft its own environmental sustainability program, nevertheless, there are instances where waste disposal \& other environmental management program were ineffectively mobilized.

A classic example for this is the waste collection systems in Nepal, which, were not properly 
planned to effectively utilize available resources. In lieu of that, it is estimated that the 58 municipalities in Nepal generate about 1,369 tons of municipal waste per day or 500,000 tons per year (SWMRMC, 2004).

Indeed, the crafting of innovative advocacy framework may be seen as central to the environmental sustainability program implementation. Yet, past experiences have yielded less than impressive results. Many strengthening programs have not been sustained after the completion of externally funded projects. With this, what institutional innovations are needed to successfully manage the newly created program? Very little empirical evidence is available to answer this challenging issue.

It is, therefore, timely to conduct a review and evaluation on the existing environmental sustainability programs, to identify other aspects that necessitate further improvement and innovations.

\section{Methodology}

This study employed a descriptive-evaluative design with an end view of proposing an environmental advocacy framework. In determining its level of implementation, the researchers conducted a survey using the questionnaire adapted and modified from Cavan (2011).

The respondents of this study were three hundred fifty (350) elementary and high school teachers who were officially employed in the following schools namely Dadiangas West Central Elementary School; Dadiangas South Central Elementary School; Dadiangas East Elementary School; Balite Elementary School; GSC SPED Integrated School; Pedro Acharon Sr. Central Elementary School; Irineo Santiago National High School of Metro Dadiangas; GSC National Secondary School of Arts \& Trade; Gen. Santos City High School and Fatima National High School; for the school year 2011-2012. The distribution of the number of respondents was randomly selected by their corresponding school administrators.

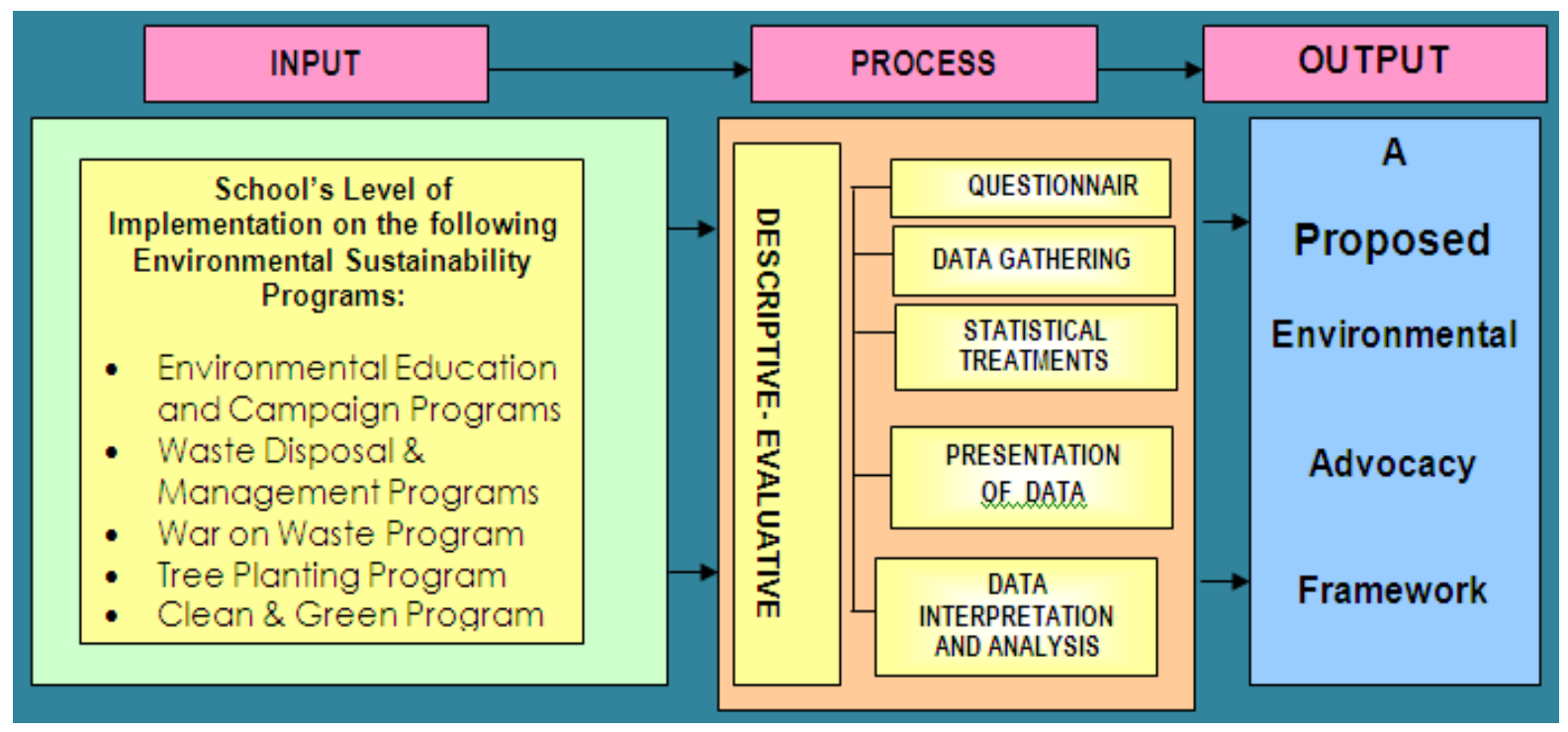

Figure 1. The Research Design 
All data gathered were processed, presented, analyzed and interpreted using weighted mean and $\mathrm{z}$ - test. The researchers analyzed and used the data as the basis in formulating an environmental advocacy framework for the public schools in General Santos City.

This proposed advocacy framework, however, is in line with the strategic direction of P.D. 1151 (Philippine Environmental Policy). It searched for ways on how to achieve increased sustainability of the environmental sustainability programs implemented in schools.

\section{Results and Discussion}

\subsection{Level of Implementation of the Environmental Sustainability Programs in Selected} Elementary and Secondary Schools of GSC

The degree of implementation of the environmental sustainability programs, presented in Table 1, has an aggregate mean of 3.32 for elementary and 2.99 for secondary schools, described as moderately implemented.

Specifically, for the elementary schools, components 1,2 , and 4 are rated moderate in implementation, but high in components 3, 5 and 6. In secondary schools, all programs were rated moderate except for the tree planting program which was rated fair in implementation.

These results indicate that the majority of the environmental sustainability programs of elementary and secondary schools were included in the strategic plan of the schools and that they were reasonably performed and mediocre in its implementation. Hence, elementary and secondary schools of GSC need to apply innovative course on environmental education and advocacy, which are important components in order to help sustain and enhance their existing environmental programs. This result supports the findings of Mercado (1998) that the significance of education and advocacy as an integrated element of an environmental agenda cannot be overstated.

Table 1. Implementation Level of the Environmental Sustainability Programs in Elementary and Secondary Schools of General Santos City

\begin{tabular}{|l|c|c|c|c|}
\hline \multicolumn{1}{|c|}{$\begin{array}{c}\text { Components of } \\
\text { Different } \\
\text { Environmental } \\
\begin{array}{c}\text { Sustainability } \\
\text { Programs }\end{array}\end{array}$} & $\begin{array}{c}\text { Elementary } \\
\bar{x}\end{array}$ & Description & $\begin{array}{c}\text { Secondary } \\
\bar{x}\end{array}$ & Description \\
\hline $\begin{array}{l}\text { 1. Environmental } \\
\text { Education \& } \\
\text { Campaign } \\
\text { Program }\end{array}$ & 3.35 & $\begin{array}{c}\text { Moderately } \\
\text { Implemented }\end{array}$ & 3.33 & $\begin{array}{c}\text { Moderately } \\
\text { Implemented }\end{array}$ \\
\hline $\begin{array}{l}\text { 2. Waste Disposal } \\
\text { \& Mgt Programs }\end{array}$ & 3.33 & $\begin{array}{c}\text { Moderately } \\
\text { Implemented }\end{array}$ & 2.96 & $\begin{array}{c}\text { Moderately } \\
\text { Implemented }\end{array}$ \\
\hline 3. War on Waste & 3.59 & Highly & 3.14 & Moderately \\
\hline
\end{tabular}




\begin{tabular}{|l|c|c|c|c|} 
Program & 2.59 & $\begin{array}{c}\text { Implemented } \\
\text { Implemented }\end{array}$ & 2.35 & $\begin{array}{c}\text { Implemented } \\
\text { Program }\end{array}$ \\
\hline $\begin{array}{l}\text { 5. Clean \& Green } \\
\text { Program }\end{array}$ & 3.58 & $\begin{array}{c}\text { Highly } \\
\text { Implemented }\end{array}$ & 3.14 & $\begin{array}{c}\text { Moderately } \\
\text { Implemented }\end{array}$ \\
\hline $\begin{array}{l}\text { 6. Protection \& } \\
\text { Conservation }\end{array}$ & 3.46 & $\begin{array}{c}\text { Highly } \\
\text { Implemented }\end{array}$ & 3.01 & $\begin{array}{c}\text { Moderately } \\
\text { Implemented }\end{array}$ \\
\hline Over-all & 3.32 & $\begin{array}{c}\text { Moderately } \\
\text { Implemented }\end{array}$ & 2.99 & $\begin{array}{c}\text { Moderately } \\
\text { Implemented }\end{array}$ \\
\hline
\end{tabular}

4.2 Difference between Elementary and Secondary Schools on the Level of Implementation in Environmental Sustainability Programs

Z-test was employed to determine the difference between the responses of 174 elementary and 176 secondary school teachers. As shown in table 2, elementary schools have higher level of implementation on its environmental program compared to high schools. This is shown by the higher mean for elementary schools $(\mathrm{wm}=3.32)$ and the lower mean for high schools $(\mathrm{wm}=$ 2.99). Since $\mathrm{p} \leq .05$, then there is a significant difference in their level of implementation. The null hypothesis which states that there is no significant difference between the elementary and high schools is therefore rejected.

Table 2. Difference on the Level of Implementation of the Environmental Sustainability Programs between Elementary and Secondary Schools of General Santos City

\begin{tabular}{|l|c|c|c|c|c|c|}
\hline \multirow{2}{*}{$\begin{array}{l}\text { Components } \\
\text { of Different } \\
\begin{array}{l}\text { Environmental } \\
\text { Sustainability } \\
\text { Programs }\end{array}\end{array}$} & \multicolumn{5}{|c|}{ Difference in the Level of Implementation } & \\
\cline { 2 - 7 } & Elementary & Secondary & z-computed & p-value & z-critical & Remarks \\
\hline $\begin{array}{l}\text { Envi Educ \& } \\
\text { Campaign } \\
\text { Program }\end{array}$ & 3.35 & 3.33 & 0.26 & 0.80 & 1.96 & $\begin{array}{l}\text { Not } \\
\text { Significant }\end{array}$ \\
\hline $\begin{array}{l}\text { Waste } \\
\text { Disposal \& } \\
\text { Mgt Programs }\end{array}$ & 3.33 & 2.96 & 3.14 & 0.002 & 1.96 & Significant \\
\hline $\begin{array}{l}\text { War on Waste } \\
\text { Program }\end{array}$ & 3.59 & 3.14 & 3.47 & 0.001 & 1.96 & Significant \\
\hline $\begin{array}{l}\text { Tree Planting } \\
\text { Program }\end{array}$ & 2.59 & 2.35 & 2.00 & 0.04 & 1.96 & Significant \\
\hline
\end{tabular}




\begin{tabular}{|l|c|c|c|c|c|l|}
\hline $\begin{array}{l}\text { Clean \& } \\
\text { Green } \\
\text { Program }\end{array}$ & 3.58 & 3.14 & 3.20 & 0.001 & 1.96 & Significant \\
\hline $\begin{array}{l}\text { Protection \& } \\
\text { Conservation }\end{array}$ & 3.46 & 3.01 & 3.54 & 0.000 & 1.96 & Significant \\
\hline Over-all & 3.32 & 2.99 & 3.20 & 0.001 & 1.96 & Significant \\
\hline
\end{tabular}

Results show that all environmental sustainability programs except for component 1 are found to be significant. The p-value which is less than 0.05 level of significance implies that there is a significant difference in the level of implementation between elementary and secondary schools.

This indicates that school administrators together with the teachers have notable planning on environmental programs; however, these programs do not fully implement strategizing processes that meet established objectives and lifestyle disciplines among the school principals, educators, learners and other stakeholders. With this, environmental assessment must be stressed to give its stakeholders and the community critical information on the project performance, flexibility, impact and shortcomings.

Countless reports have been written on environmental sustainability, but few have approached this specifically from an outlook that strengthens institutions and human participation is still lacking.

\section{Conclusion and Recommendations}

The heightened ecological dilapidation of this generation is noted as one of the pressing concerns that necessitate the collaborative effort among faculty, staff, students and the community. Environmental sustainability is more than just a conjecture, but a strong responsibility of all stakeholders especially in the diverse public institutions.

Based from the teachers' evaluation, it was found out that generally, the sustainability programs of the public elementary and secondary schools were moderately implemented. The results also revealed that all environmental sustainability programs except for the first component are found to be significant. Moreover, there is a significant difference on the level of environmental sustainability program implementation between elementary and secondary schools. Generally, elementary schools have higher level of implementation than high schools. These findings also imply that the environmental strategic plan of elementary and high schools were mediocre in its implementation. Hence, based from the gathered data and suggestions offered, this study proposed an innovative environmental advocacy framework to help sustain and enhance the implementation of their existing environmental programs.

\subsection{Environmental Advocacy Framework (EAF)}




\section{Macrothink}

Environmental Management and Sustainable Development

ISSN 2164-7682

2012, Vol. 1, No. 2

To significantly increase social responsibility and accountability of the students, teachers,

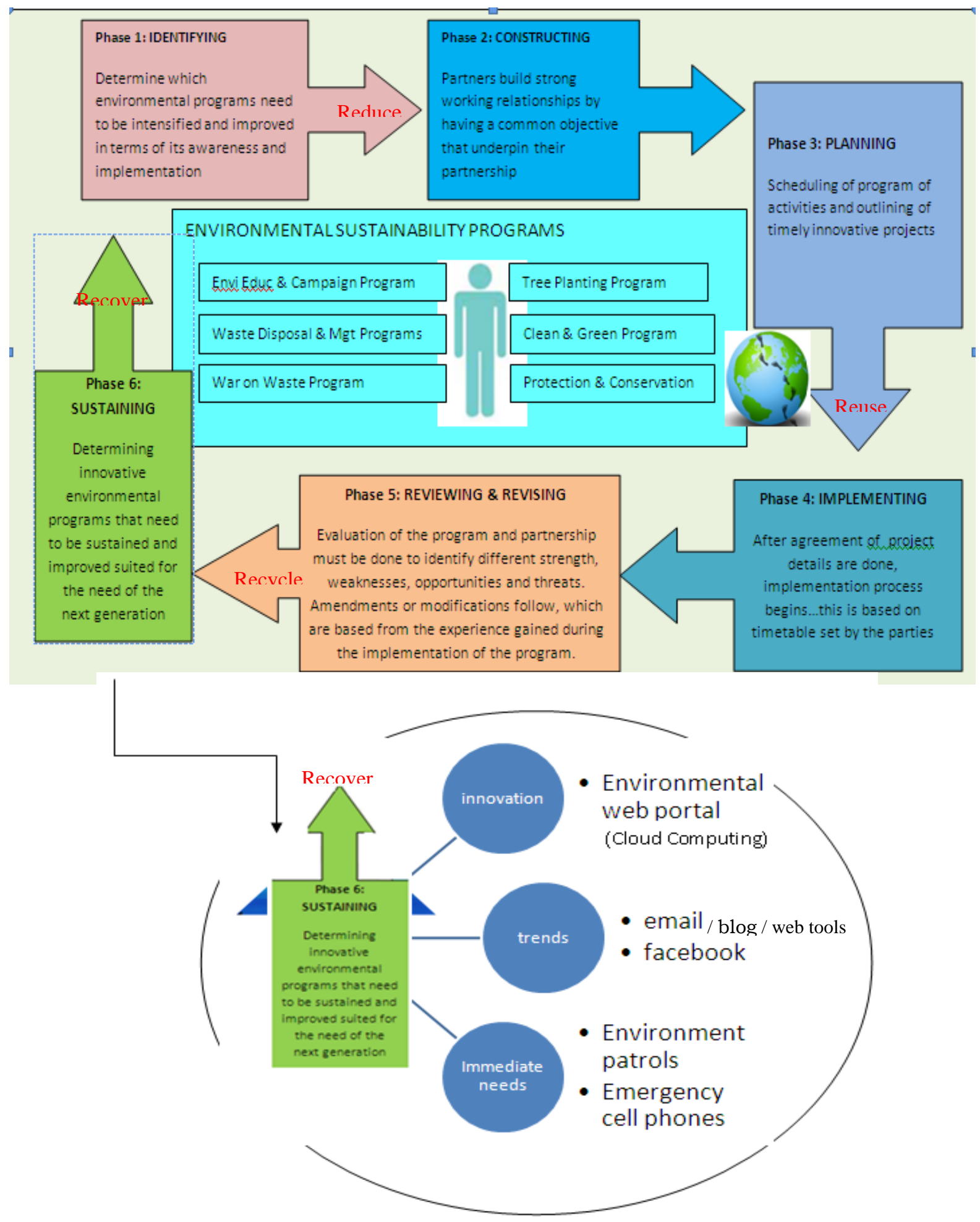

Figure 2. Environmental Advocacy Framework

GOs/NGOs and community organizations, an innovative environmental advocacy framework is essential for a more effective implementation. The purpose of this EAF is to outline the steps needed to effectively implement the framework. It also attempts to specify possible 
future directions for integrated assessment based on current trends and initiatives.

This advocacy has to start from the academe as one of the stakeholders that sought innovative ways to reinforce schools' level of execution of the environmental sustainability programs and engage people to respond to the identified environmental issues. Next, this advocacy initiative must continue to explore other means to increase participation.

There are six (6) phases outlined in the Environmental Advocacy Framework which are the following: Identifying, Constructing, Planning, Implementing, Reviewing and Revising, and Sustaining.

Phases 1, 2 and 3 require the identification, construction and planning of target environmental programs to be intensified or improved. This also entails establishing strong partnerships and creating a program outlining timely innovative projects.

Phase 4 of the framework indicates the start of the implementation process based on the timetable set by concerned parties. This is followed by Phase 5 which is the evaluation part and is done by conducting the SWOT analysis to identify the strengths, limitations, opportunities and other concerns of the program and partnership.

Phase 6 determines innovative environmental programs that need to be sustained and improved suited for the next generation. This can be made possible by having environmental cloud computing webs and integration of other technological schemes appropriate to the need of the current and future generations.

It is, therefore, recommended that in this millennium, annual appraisal of strategic plan to identify the gaps in the implementation of their school's environmental sustainability program must be done to strengthen the school's environmental advocacy. This is made possible by encouraging collaboration among their constituents, which can be achieved through the following initiatives: continuous environmental training and awareness programs; suggestion program to campaign for innovative ways to sustain the schools' environmental programs; the use of innovative trends such as "blog" and other educational web tools towards environmental care; raising the needed funds for environmental activities including an attractive reward systems to boost stakeholders’ participation.

The quest for environmental improvement has to be framed not only in terms of science and new technologies, but also to benefit from the wisdom and values espoused by students, teachers and its stakeholders. Educators and educational systems can respond more vigorously to this global challenge with new approaches, information know-how, and partnerships on national and even on international levels.

Finally, school principals should consider an evaluation to identify the strength, weaknesses, opportunities and threats of environmental programs implemented on a regular basis to facilitate a realistic environmental advocacy framework.

\section{Acknowledgement}




\section{Macrothink}

Environmental Management and Sustainable Development

ISSN 2164-7682

2012, Vol. 1, No. 2

The research is supported by the Department of Education, General Santos City, Philippines. My sincere gratitude to the School's Division Superintendent, Principals and Departments Heads for the support they extended.

\section{References}

Baula, Enrico. (2010). School-Based Solid Waste Management Initiative in the Philippines: Lessons and Experiences of the Toyota Auto Parts and Sta. Rosa City Partnership. Retrieved on $\quad$ February 2012 from http://www.arsa1996.org/pictures/pdf/ARSA_IV_PRCDGS_VOL2/PARTNERSHIP\%20AN D\%20COLLABORATION\%20TOWARDS\%20IMPROVING\%20RURAL\%20LIVELIHO ODS/5.\%20BAULA_205-214.pdf.

Briones, Nicomedes D. (2005). Environmental Sustainability Issues in Philippine Agriculture. Asian Journal of Agriculture and Development, 2(1-2), 67-78.

Cavan, Marco. (2011). The Level of Implementation of the Environmental Sustainability Programs in Schools of Alabel as Influenced by the Teachers', Students' and Pupils' Participation in the Programs. A Master’s Thesis, Mindanao State University, GSC.

Greene, Kevin. (2008). Planning for Campus Sustainability. Retrieved on November 2011 from http://www.epa.state.il.us/p2/presentations/campus-sustainability.pdf.

Jucker, Rolf. (2003). UNESCO’s Teaching and Learning for a Sustainable Future: A Critical Evaluation, Trumpeter, 19(2).

Mercado, Ruben G. (1998). Environmental and Natural Resources Management: Lessons from City Program Innovations. Philippine Journal of Development, XXV(1), 147-180.

Paje, Ramon. (2011). National Search for Sustainable and Eco-Friendly Schools. Retrieved on January 2012 from http://sustainableschools.ph/whatsnew.html

SWMRMC. (2004). A Diagnostic Report on State of Solid Waste Management in Municipalities of Nepal, Solid Waste Management and Resource Mobilization Centre, Lalitpur.

\section{Copyright Disclaimer}

Copyright reserved by the author(s).

This article is an open-access article distributed under the terms and conditions of the Creative Commons Attribution license (http://creativecommons.org/licenses/by/3.0/). 